\title{
The Effectiveness of Public Policies in Promoting Responsible Business Conduct: Rates of Elective Cesarean Sections versus Vaginal Deliveries in Public and Private Healthcare Networks in Brazil
}

\section{La efectividad de las políticas públicas en la promoción de conductas empresariales responsables: La tasa de cesáreas electivas versus partos vaginales en redes de salud públicas y privadas en Brasil}

Mariana KaIPPER de AzeVEDo ${ }^{1}$

\begin{abstract}
This article analyses the effectiveness of public policies in promoting responsible business conduct in terms of the high rates of elective cesarean sections in Brazil. This frequency runs counter to the recommendations of the World Health Organization, which states that cesarean sections should only be performed when clinically necessary when the health of the mother or child is at risk. The government, which is responsible for protecting fundamental rights that include health, must ensure that public and private health care networks act in the best interest of its citizens. This study involves data collection, bibliographic research, and a review of the legislation, and concludes that although Brazil has numerous public policies to
\end{abstract}

\footnotetext{
${ }^{1}$ Lawyer (Pontifícia Universidade Católica do Paraná). Postgraduate student (lato
} sensu) in Constitutional Law (Academia Brasileira de Direito Constitucional). 
encourage vaginal delivery, these initiatives disregard the determining factors that lead to elective cesarean births.

Keywords: public policies, human rights, responsible business conduct, Brazil, elective cesarean section, vaginal delivery.

Resumen: Este artículo analiza la efectividad de las políticas públicas para promover una conducta empresarial responsable en términos de las altas tasas de cesáreas electivas en Brasil. Estas van en contra de las recomendaciones de la Organización Mundial de la Salud, que establece que las cesáreas solo deben realizarse cuando sea clínicamente necesario cuando la salud de la madre o el niño esté en riesgo. El gobierno, que es responsable de proteger los derechos fundamentales que incluyen la salud, debe garantizar que las redes de atención médica públicas y privadas actúen en el mejor interés de sus ciudadanos. Este estudio involucra recolección de datos, búsqueda bibliográfica y revisión de la legislación, y concluye que si bien Brasil cuenta con numerosas políticas públicas para incentivar el parto vaginal, estas iniciativas desconocen los factores determinantes que conducen a la cesárea electiva.

Palabras clave: políticas públicas, derechos humanos, conducta empresarial responsable, Brasil, cesárea electiva, parto vaginal.

Recibido: 6.10.2020 Aceptado: 20.12.2020

\section{Summary}

\section{Introduction}

2. Medical Recommendations Regarding Childbirth

3. The State's Role

4. Obstacles to Public Policies Encouraging Vaginal Birth

5. Conclusions 


\section{Introduction}

The childbirth options available to pregnant women depend on the public policies adopted in their countries. In Brazil, health services are provided not only by the government, but also by private initiative. As such, public policies address both types of healthcare providers and include policies on delivery options. Although these policies apply to the domestic environment, they reflect international commitments expressed by various bodies affiliated with the United Nations.

The 2030 Agenda for Sustainable Development, drafted by the UN in 2015, established seventeen Sustainable Development Goals (SDGs) to build a balanced society in which present and future generations can enjoy quality of life and full human rights (Nações Unidas Brasil, 2015a). SDG 3 is related to ensuring a healthy life and promoting well-being for everyone at all ages; it comprises several targets including reducing maternal and neonatal mortality and guaranteeing access to sexual and reproductive health services (Nações Unidas Brasil, 2015b).

Childbirth is just one component of women's sexual and reproductive health. The right to humanized childbirth is a platform of feminist movements and involves women's right to have their individuality, choices, and health respected when they are giving birth. Although women clearly take an active role in this process, it is currently surrounded by excessive medicalization.

Within the UN system, the World Health Organization (WHO) is dedicated to ensuring that all people everywhere have access to quality health (World Health Organization, n.d.a). This specialized body specifically focuses on improving the health of mothers and newborns (World Health Organization, n.d.b). The WHO supports humanization, including eliminating obstetric violence and the right to have a companion present during birth (World Health Organization, 2018). The United Nations Children's Fund (UNICEF) is 
another part of the United Nations founded to protect children's rights from birth (UNICEF, 2017).

Within this context, SDG 17 involves cooperation from private enterprise for sustainable development, which is relevant in Brazil where health services are also provided by private initiative (Nações Unidas Brasil, 2015a).

Even prior to the drafting of Agenda 2030, the 2000 United Nations Global Compact (a corporate sustainability initiative) called for business to share responsibility in addressing society's challenges, especially with regard to human rights (UN Global Compact, n.d.). In 2011, the UN also presented its Guiding Principles on Business and Human Rights, which featured protection and respect for human rights and reparations when they are violated. In other words, private initiative that is active in the area of women's and children's health has been expected to adopt practices that protect and respect the fundamental right to health, including during delivery.

The international organizations cited above present vaginal delivery as ideal for both mother and newborn, based on medical studies in obstetrics, pediatrics, and women's health and the opinions of organizations founded to protect the health of these individuals.

In a neoliberal society, where essential services such as health fall within the domain of private initiative and are consequently monetarized (as if life, health, or well-being were measurable in capital), business responsibility for the health of women and newborns must be considered.

For this reason, this article analyzes public policies proposed by the Brazilian government to encourage vaginal deliveries in public and private health care networks, investigating current initiatives and the effectiveness of statistics on childbirth in Brazil and identifying financial and cultural obstacles to the functioning of public policies. 


\section{Medical Recommendations Regarding Childbirth}

Childbirth can take various forms, including vaginal delivery, elective cesarean section, and unplanned cesarean section. This article discusses the choice between elective cesarean section and vaginal delivery. While there are clearly cases in which medical recommendations lead women to abandon vaginal birth, this research focuses on high numbers of elective cesarean sections where there is no medical recommendation for surgery, specifically due to the various negative impacts and complications that result from these procedures.

The WHO has revealed that maternal deaths from cesarean sections are 100 times greater in developing countries, and result in up to one third of newborn deaths (Sobhy et al., 2019). A study by Sobhy et al. found that even though many women who need cesarean sections do not have access to this procedure, many others undergo it without medical justification (2019).

There are many reasons behind high elective cesarean rates around the world, and any incentives to reduce this number require explanations that involve cultural rules involving women and health systems. Sobhy et al. determined that cesarean sections can result in negative consequences in the short term and also that can last for years after birth, to the detriment of women, children, and future pregnancies. The study included a global map of maternal death risk after cesarean section in women in low-to-middle-income countries, reproduced below:

Map 1 - World map of maternal death risk after cesarean section in women in low-to-middle-income countries 


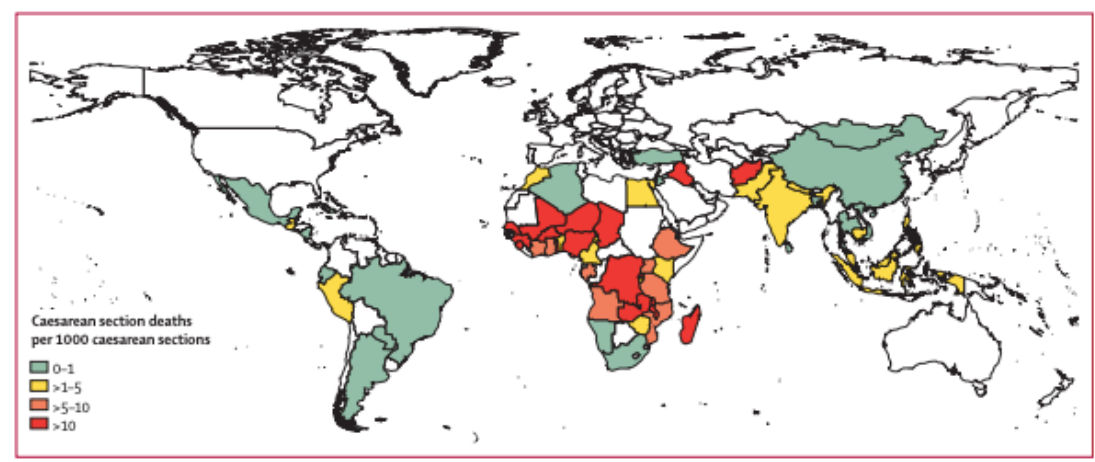

Source: Sobhy, Soha et al. 2019. "Maternal and Perinatal Mortality and Complications Associated with Caesarean Section in Low-Income and Middle-Income Countries: a Systematic Review and Meta-Analysis." The Lancet 393, no. $10184 \quad$ (March): 1973-82. 11, 2019. https://doi.org/10.1016/S0140-6736(18)32386-9

Although Brazil does not suffer from maternal mortality due to cesarean sections, UNICEF (in its Brazil-specific report entitled Quem espera, espera) details the advantages of waiting for labor to begin naturally, such as greater weight gain and brain and lung maturity in the new infant during the final weeks of pregnancy (UNICEF, 2017). It describes the findings of a Brazilian study on birth indicating that babies born in weeks 37 and 38 of gestation (not premature) more frequently require neonatal intensive care compared to those born in weeks 39 through 41 (Barros, 2012). Additionally, vaginal birth may strengthen the infant's immune system and prevent type I diabetes and allergies (UNICEF, 2017). Besides more respiratory problems, higher mortality risk and growth deficit are also associated with cesarean section prior to spontaneous labor (that is, elective cesarean section scheduled without a clinical justification) (Barros, 2012).

As for the health of laboring women, the same report shows that recovery from vaginal delivery is faster and less painful than after cesarean section, and medication is generally not needed (UNICEF 
2017 , p. 10). Furthermore, because the mother is able to interact with her child immediately after birth the mother-child bond is strengthened (UNICEF 2017, p. 10).

For pregnant women with no risk of complications from childbirth, cesarean section can unnecessarily lead to an assortment of health problems including intense postpartum pain, higher risk of infection, hemorrhage, sequelae (such as organ damage), longer recovery time, complications in future pregnancies, kidney problems, difficulty breastfeeding, postpartum depression, and hospitalization (UNICEF, 2017, p. 11).

It is consequently evident that vaginal delivery poses less risk to the mother and child and should be preferred. And yet the 2017 UNICEF report found that Brazil ranks second in the world for percentage of births by cesarean section (UNICEF, 2017).

According to the $\mathrm{WHO}$, the maximum cesarean rate should be $15 \%$ of total births. Brazil's Ministry of Health, however, considers the ideal parameter 25-30\%, taking into account the specific characteristics of the Brazilian population (Comissão Nacional de Incorporação de Tecnologias do SUS, 2016a, p. 19). While this percentage exceeds the internationally established ideal, it is still much lower than the actual rate: in 2018, cesarean sections accounted for $55.94 \%$ of births in the country (Departamento de Saúde e Vigilância de Doenças Não Transmissíveis, n.d.).

Moreover, when carefully analyzed, the data revealed that $42.81 \%$ of births in public facilities were cesarean sections, while this number reached $67.63 \%$ in private ones (Departamento de Saúde e Vigilância de Doenças Não Transmissíveis, n.d.). According to the Brazilian National Supplementary Health Agency (Agência Nacional de Saúde Suplementar, ANS), cesarean rates are even higher for births covered by health plans, at $83 \%$ (Agência Nacional de Saúde Suplementar, n.d.a). 
As mentioned previously, the right to health for pregnant women and newborns is an international consensus, and should be safeguarded even by private initiative. It is consequently up to the government to institute public policies that preserve the health of women and infants, as explained below.

\section{The State's Role}

The capitalist, globalized, and increasingly neoliberal society in which we live has yielded to pressure to reduce government interventions and transfer many functions to private entities, removing the state from its position as the sole guarantor of human rights. Although governments have been partially excluded from the current model, they are still subject to international accountability when human rights are neglected at the national level. It is the duty of the state to monitor private initiative, for example through regulatory agencies. Countless public policies can be implemented to benefit social rights.

Here I analyze the specific organization of the Brazilian health system and relevant public policies because of the strikingly different rates of cesarean births in public and private health care networks.

\section{a. Organization of the Brazilian Health System}

Brazil has a unified public health system (Sistema Única de Saúde, SUS) and a private health network regulated by the ANS. This regulatory agency controls and supervises companies that work in health (health plan operators), a topic of public interest since it directly affects a fundamental right of Brazilian citizens (Agência Nacional de Saúde Suplementar, n.d.b).

In the private system, health plan operators intermediate payment between patients and health professionals. This establishes a consumer relationship in which clients choose the professionals 
associated with the plan; there may also be direct contracting between patients and professionals, without intermediation.

Meanwhile, the SUS is responsible for health activities and services provided by federal, state, and municipal public agencies and institutions that are directly and indirectly administered, as well as government-supported foundations established in Article 4 of Law 8080/1990 (Brasil, 1990). As a system composed of government administrations, the SUS is governed by the principles of public administration that include impersonality, as detailed in Article 37 of the Brazilian Federal Constitution (Brasil, 1988). This establishes that health care in this system is to be provided without prejudice or privilege in line with the principle of equality, also according to Article 7 of Law 8080/1990.

The professionals who work in the SUS consequently represent the government, and there is no personal hiring link with the patient, unlike private providers. Prenatal and birth-related care involves staff that may vary according to availability. Prenatal care is provided in a Basic Health Unit, and birth takes place in a maternity hospital (Ministério da Saúde, 2013). However, the SUS may use private establishments via contracts or agreements, remunerating these providers for coverage according to the criteria found in Articles 24 and 26 of Law 8080/1990.

\section{b. Ways of Encouraging Vaginal Delivery}

States can implement legislation, administrative actions, and public policies to ensure fulfillment of human rights (Comissão Interamericana de Direitos Humanos, 1969). To comply with WHO recommendations on childbirth, Brazil has adopted a public policy to encourage vaginal delivery, providing national guidelines on vaginal birth (Comissão Nacional de Incorporação de Tecnologias no SUS, 2016b) and cesarean procedures (Comissão Nacional de Incorporação de Tecnologias no SUS, 2016a). These guidelines are intended to humanize childbirth, discouraging medically 
unnecessary cesarean sections since they involve greater risks for mother and baby, and are in line with WHO recommendations. They form the foundation for administrative activities that provide guidance to professionals and public and private health institutions on when cesarean sections are recommended over vaginal delivery. The SUS follows these guidelines by law (Brasil, 1990); they state that cesarean sections should only be performed when natural birth is impossible (in other words, only when clinically necessary) (Comissão Nacional de Incorporação de Tecnologias no SUS, 2016a; Comissão Nacional de Incorporação de Tecnologias no SUS, 2016b).

The SUS and ANS include birth care by an obstetric nurse during delivery among the procedures offered to encourage vaginal birth, since these professionals are not authorized to perform surgery. According to the guidelines cited above, this option provides advantages in reducing interventions and increasing satisfaction among women. ANS Resolution 36/2008, which regulates obstetric and neonatal care services, also requires non-pharmacological pain relief options as part of the structure for care provided to women delivering vaginally (Brasil, 2008).

Within the SUS, there are centers for vaginal childbirth through a program specifically for expectant mothers (Rede Cegonha, the "Stork Network") (Brasil, n.d.) where laboring women are accompanied by obstetric nurses or obstetricians in an adequate environment with space for movement and access to non-pharmacological methods of pain relief (Brasil, 2015). Prior to labor, pregnant women receive an informational booklet through the same program to monitor their pregnancy. This booklet describes cesarean section as a major surgery that should only take place when justified by risk to the baby or mother. Contrary to widespread belief, it is not presented as a birth option (Ministério da Saúde, 2016). The booklet also emphasizes the importance of labor in preparing the body for birth and in the infant's lung and immune system development. Even when cesarean section is necessary, waiting for labor benefits the mother and the baby; in 
other words, if a cesarean section is required, it should ideally occur after labor begins, not on a previously-scheduled basis.

For any medical procedure, legislation requires patients to sign a consent form informing them of risk, in accordance with Article 22 of the Brazilian Code of Medical Ethics (Conselho Federal de Medicina, 2009). This consequently implies that the risks of cesarean surgery will be explained to patients via a consent form.

Other activities by the Ministry of Health to encourage vaginal delivery include raising the remuneration for vaginal delivery and limiting payment for cesarean sections performed by the SUS, financing specialization courses in obstetric nursing, a program for training traditional childbirth attendants ("Trabalhando com Parteiras Tradicionais”), doula training, and a plan in partnership with ANS to reduce unnecessary cesarean births (Ministério da Saúde, 2010). And the Supplementary Health Qualification Programs (Agência Nacional de Saúde Suplementar, n.d.c), an initiative to give consumers insight into the quality of health plans, include better scores for health plan operators with fewer cesarean births (Agência Nacional de Saúde Suplementar, 2015a).

The ANS also carries out awareness campaigns and develops educational materials to encourage vaginal delivery (Agência Nacional de Saúde Suplementar, 2015a). It ensures access to information by making data available on cesarean rates and vaginal deliveries according to health care plan, doctor, and medical institution (Agência Nacional de Saúde Suplementar, 2015b). A pilot plan was also developed to implement strategies in private hospitals to reduce cesarean rates (Agência Nacional de Saúde Suplementar, n.d.d).

In summary, public policies in Brazil include adapting the structure at birth assistance sites, vocational training, access to information, financial incentives, and action plans to encourage vaginal delivery. However, the data shows that these initiatives are not yielding the desired effect, since cesarean rates in Brazil remain very 
high. Obstacles contributing to this outcome will be analyzed in the following section.

\section{Obstacles to Public Policies Encouraging Vaginal Birth}

In Brazil, cesarean rates exceed the recommendations from health agencies. To investigate the reasons for this phenomenon, we must examine the financial and cultural aspects surrounding childbirth that impact individuals.

\section{a. The Financial Aspect}

In 2018, Cadernos de Saúde Pública, a publication of the Oswaldo Cruz Foundation, printed an article analyzing the cost-effectiveness of spontaneous vaginal delivery compared to elective cesarean section without clinical justification for non-high-risk births, from the perspective of the SUS (Entringer et al., 2018). The study identified direct costs associated with human resources, hospital supplies, capital, and administrative costs, and concluded that a vaginal delivery cost $R \$ 1,709.58$ and a cesarean section cost $R \$ 2,245.86$ in three public maternity hospitals in the states of Rio de Janeiro and Minas Gerais.

Meanwhile, a second article by Paixão, De Souza, and Lima (2010) compared the costs of vaginal delivery and cesarean section at a public teaching hospital in the state of Minas Gerais. The table below describes the activities involved in both procedures:

Table 1 - Activities performed in both vaginal delivery and cesarean section

\begin{tabular}{|l|l|}
\hline Activities & Description \\
\hline 1 - Reception & $\begin{array}{l}\text { Patient arrives at the hospital's } \\
\text { reception desk; patient record is } \\
\text { created before triage. }\end{array}$ \\
\hline
\end{tabular}




\begin{tabular}{|l|l|}
\hline 2 - Triage & $\begin{array}{l}\text { Patient is examined by the medical } \\
\text { team, which indicates which } \\
\text { procedure is to be performed. }\end{array}$ \\
\hline 3 - Admission to the obstetric ward & $\begin{array}{l}\text { Patient is transferred to the pre- } \\
\text { partum room, where she is prepared } \\
\text { for the procedure. }\end{array}$ \\
\hline 4 - Delivery & $\begin{array}{l}\text { Delivery takes place according to } \\
\text { medical indication: vaginal delivery } \\
\text { or cesarean section. }\end{array}$ \\
\hline 6 - Nost-operative admission & $\begin{array}{l}\text { After delivery, the patient is } \\
\text { transferred to a post-operative } \\
\text { recovery room. }\end{array}$ \\
\hline 7 - Discharge & $\begin{array}{l}\text { The newborn is transferred to the } \\
\text { nursery for pediatric assessment } \\
\text { and first bath. }\end{array}$ \\
\hline & $\begin{array}{l}\text { Conditions of patient and newborn } \\
\text { are verified; if no problems are } \\
\text { found, both are discharged. }\end{array}$ \\
\hline
\end{tabular}

Source: Paixão, Erivelto M., Antônio A. De Souza, Lívia C. M. Lima. 2010.

"Custo do parto normal e cesáreo: replicação do custeio ABC," XVII

Congresso Brasileiro de Custos.

https://anaiscbc.emnuvens.com.br/anais/article/view/686/686.

These authors also reported the different costs of the activities involved in vaginal delivery and cesarean section:

Table 2 - Different costs of the activities involved in vaginal delivery and cesarean section

\begin{tabular}{|l|l|l|}
\hline Activities & Vaginal delivery R\$ & Cesarean section R\$ \\
\hline Process 1 - Reception & 2.60 & 2.60 \\
\hline Process 2 - Triage & 11.43 & 11.43 \\
\hline Process 3 - Admission & 93.28 & 178.28 \\
\hline Process 4 - Delivery & 583.51 & 781.02 \\
\hline $\begin{array}{l}\text { Process 5 - Post- } \\
\text { operative admission }\end{array}$ & 106.66 & 110.62 \\
\hline Process 6 - Nursery & 19.35 & 19.35 \\
\hline
\end{tabular}




\begin{tabular}{|l|l|l|}
\hline Process 7 - Discharge & 137.74 & 141.68 \\
\hline Total cost & 954.58 & $1,244.99$ \\
\hline
\end{tabular}

Source: Paixão, Erivelto M., Antônio A. De Souza, Lívia C. M. Lima. 2010.

"Custo do parto normal e cesáreo: replicação do custeio ABC," XVII Congresso Brasileiro de Custos.

https://anaiscbc.emnuvens.com.br/anais/article/view/686/686.

Next, the difference between the total cost of these procedures and the values paid by the SUS for this care was determined:

Table 3 - Differences between the total procedure cost and SUS compensation

\begin{tabular}{|l|l|l|}
\hline & Vaginal delivery R\$ & Cesarean section R\$ \\
\hline SUS Payment & 470.25 & 599.56 \\
\hline Total Cost & 954.88 & $1,244.99$ \\
\hline Profit/Loss & -484.33 & -645.43 \\
\hline
\end{tabular}

Source: Paixão, Erivelto M., Antônio A. De Souza, Lívia C. M. Lima. 2010. "Custo do parto normal e cesáreo: replicação do custeio ABC," $X V I I$ Congresso Brasileiro de Custos.

https://anaiscbc.emnuvens.com.br/anais/article/view/686/686.

These authors found that both the teaching hospital and the SUS lose more money on cesarean sections compared to vaginal delivery. A more recent study by Entringer, Pinto, and Gomes (Entringer, Pinto, and Gomes, 2019) determined that:

the average cost of vaginal delivery was $R \$ 808.16$ and varied from $R \$ 585.74$ to $R \$ 916.14$ in the maternity hospitals. The average cost of elective cesarean section was $R \$ 1,113.70$, ranging from $R \$ 652.69$ to $R \$ 1,516.02$. The main cost item was staff costs for both procedures. Including the rooming-in period, the average cost of vaginal delivery was $R \$ 1,397.91$ (R\$1,287.50-1,437.87), while cesarean section was 32\% higher at $R \$ 1,843.8791(R \$ 1,521.54-2,161.98)$ 
A 2013 article by De Souza et al. collected the same data for a private hospital in Minas Gerais (De Souza et al., 2013), and found the following differences between the costs and the health plan payouts for each procedure:

Table 4 - Difference between procedure cost and health plan compensation

\begin{tabular}{|l|l|l|l|}
\hline Delivery form & $\begin{array}{l}\text { Procedure cost } \\
\mathrm{R} \$\end{array}$ & $\begin{array}{l}\text { Health plan } \\
\text { compensation R\$ }\end{array}$ & $\begin{array}{l}\text { Difference } \\
\text { between cost } \\
\text { and revenue R\$ }\end{array}$ \\
\hline $\begin{array}{l}\text { Vaginal } \\
\text { delivery }\end{array}$ & 483.91 & 386.52 & 97.39 \\
\hline $\begin{array}{l}\text { Cesarean } \\
\text { section }\end{array}$ & 703.27 & 511.55 & 191.72 \\
\hline
\end{tabular}

Source: De Souza, A. A. et al. "Análise de Custos em Hospitais: Comparação dos Custos dos Partos Normal e Cesáreo e os Valores Repassados por um Plano de Saúde," 50-61.

The difference between the actual cost and the value paid by the plan is absorbed by the hospital. We can thus conclude that cesarean section is not economically advantageous for private hospitals or health plans, which both bear higher costs than when women deliver vaginally.

The studies cited above did not analyze the remuneration of the professionals involved in delivery. However, compensation for professionals who assist in delivery in the SUS is defined by law: R\$ 110.00 for vaginal delivery and $\mathrm{R} \$ 102.00$ for cesarean section (Brasil, 2000). According to the ANS, payment to health professionals in the private sector may vary as follows (Agência Nacional de Saúde Suplementar, 2017):

1. Direct payment of fees for services rendered: freely agreed between the provider (the professional) and the client (the patient) without the intervention of a third-party payer (feefor-service/out-of-pocket). 
2. Payment of fees based on a fee table for services and procedures (fee-for-service): in these cases the values are preestablished and there may be intervention from the thirdparty payer. These tables may be established within the professional corporation and negotiated with third-party paying organizations and suppliers, governments, etc.

3. Payment by case or diagnosis: case-mix (DRG) or bundled payment.

4. Payment per capita: a fixed amount per person or designated population group for a given period.

5. Wage payment for a fixed term: salary system.

6. Variable salary payment: according to volume (productivity) and quality of activities and procedures.

7. Mixed payment: part fixed payment (salary) + part variable payment (performance bonus).

Note that all payment modalities permit a differentiation between costs for vaginal delivery and cesarean section, except for the salary system.

The data shows that hospitals face losses for both forms of delivery, since SUS compensation is lower than the cost of the procedures. However, most cesarean surgeries are performed in the private health system (Departamento de Saúde e Vigilância de Doenças Não Transmissíveis, n.d.), which requires additional clarification of this discrepancy.

In practice, delivery in the private system costs much more, with values far exceeding the amounts compensated by the SUS. Furthermore, remuneration in the private system is itemized for each of the professionals involved. Cesarean procedures require a physician, anesthesiologist, birth assistant, and pediatrician; the average cost is $R \$ 6,000.00$, but this figure can reach $R \$ 12,000.00$ (Da Silva, 2021). These numbers indicate that even though the SUS compensation for this procedure is lower than the actual cost, private 
hospitals make a huge profit on cesarean sections. Vaginal delivery requires fewer professionals and can cost one third of a cesarean birth.

Finally, it should be noted that vaginal deliveries can take from 5 to 18 hours (Comissão Nacional de Incorporação de Tecnologias no SUS 2016b, p. 39) and cesarean sections only 40 to 50 minutes (Oliveira, and Penna, 2018). This makes cesarean sections even more economically advantageous for doctors in the private system, since they can perform up to 2150 -minute cesarean sections during a single vaginal birth lasting 18 hours.

\section{b. The Cultural Aspect}

According to Sobhy et al. (2019), there are many reasons for high cesarean rates around the world, and incentives to reduce this procedure should be preceded by investigations into these motives and cultural rules involving women and health systems.

The Brazilian Ministry of Health published a report in 2010 on delivery and homebirth assisted by traditional birth assistants (Ministério da Saúde, 2010). Traditionally, laboring women were assisted by midwives; during the witch hunts of the sixteenth and eighteenth centuries, these women were persecuted (along with other women with knowledge of medical practices) as part of state and church strategies to monopolize medicinal knowledge and legitimize it through universities. Midwives were gradually replaced by Peter Chamberlen's obstetric forceps up through the Scientific Revolution, in a fragmented approach to medicine that did not consider the entire human being and the surrounding environment. This situation continued, until childbirth was medicalized by the end of World War II. Cesarean section improved as science evolved, yielding better results compared to the late nineteenth century. In this way, childbirth was no longer considered a natural event, and women were considered incapable of taking a leading role in this process.

In this sense, according to an article by Bedoya-Ruiz, AgudeloSuárez, and Restrepo-Ochoa (2020), the patriarchy operates in the 
state and its institutions, and is also found in health services, since medicine has historically been masculinized. For this reason, health care workers need to understand history and transform their training and practices.

In many ways, women lack autonomy and protagonism in the process of childbirth. This includes being denied a companion during birth, prohibitions on eating or drinking during labor, and positional impositions (such as being forced to give birth lying down, which runs counter to the physiology of the birth process). Birth is far more than a medical procedure: it is a landmark in women's lives. However, it can become a negative event when their autonomy is disrespected. Emotional, social and cultural aspects must be considered.

In Brazil, a 2014 survey by Velho, Santos, and Collaço (2014) found that women researched childbirth alternatives, comparing the advantages and consequences for their children. These authors found that despite the Brazilian government's efforts to provide humanized care to pregnant women and the importance of access to information on childbirth for women, relationships between health professionals and pregnant women remain complex and women have less power to argue their preferences (Velho, Santos and Collaço, 2014).

Along these lines, the 2014 Brazilian study on childbirth quoted earlier in this text (FIOCRUZ, 2019) found that $66 \%$ of women surveyed started their pregnancy with the desire to deliver vaginally. But for those having their first birth in the private healthcare network, only $15 \%$ were supported in this preference. The same study found that among women who wished to deliver by cesarean section at the beginning of pregnancy, one of their main reasons was fear of the pain of vaginal delivery.

The article by Velho, Santos and Collaço (2014) also mentions pain as a concern. The authors found that expectations did not always match the pain women experienced. While some reported intense pain, others described it as "little stabbing pains" that were "not as bad as everyone says." The study concludes that perception of pain is 
formed by cultural context, and adds that pain can be addressed via non-pharmacological methods including the presence of a companion, position changes, massage, and access to a bath.

Bedoya-Ruiz, Agudelo-Suárez and Restrepo-Ochoa (2020) also found that perception of pain could also be linked to obstetric violence during vaginal delivery. These authors stated that research in Latin America showed that laboring women were treated brutally by medical teams. They add that women's beliefs about their own selves are invalidated, and they are silenced and judged for disobeying medical orders. Women are abandoned during labor, suffering is trivialized, and medical practices with no scientific basis are performed, with women unable to make decisions about their own bodies while the physiological and natural aspects of childbirth are ignored.

A 2012 report on obstetric violence by the Brazilian Senate Commission on Violence Against Women (Parto do Princípio, 2012) described some of the violence women suffer during vaginal birth, including the Kristeller maneuver (application of fundal pressure to the belly during the second stage of labor) and episiotomy (surgical incision to enlarge the vagina), which should not be performed without patient consent.

Other factors that lead women to choose cesarean section include beliefs that vaginal delivery will alter the vaginal anatomy and that cesarean section is a more modern method (Soalheiro, 2012). This is commonly held in Brazil, where cesarean section is considered the modern alternative, instead of a procedure to save the lives of mother and child when vaginal delivery is impossible.

This is not the case in other countries, as described in a study by Patah, and Malik (2011). These authors found that in 2000, the rate of cesarean births in Brazil was 38.9\%. The OECD's Health at a Glance (OECD, 2005) shows that this rate was second only to South Korea. Countries were divided into three groups according to frequency of cesarean births: one group with $>30 \%$ (South Korea, Italy and Mexico), 
a second group with 20-29\% (Portugal, Australia, United States, Luxembourg, Switzerland, Germany, Hungary, Canada, Ireland, Spain, New Zealand, Great Britain, and Austria), and a third group with $<20 \%$ (France, Slovakia, Denmark, Iceland, Finland, Sweden, Norway, Czech Republic, and the Netherlands). This ranking indicates that high cesarean rates are not related to modernity or development, since countries with higher human development indexes consider the procedure to be an exception.

Moreover, Oliveira, and Penna (2018) found that many of the women they surveyed stated that the type of delivery was chosen by the health provider. These authors noted that women replicate the medical discourse used to justify the cesarean section. One subject emphasized the role of the doula (a companion who offers psychological support to the mother) in making the decision, stating that the doula asked about her preferences and provided her with information to read that gave her more confidence about choosing the delivery method. The study notes that the values and meanings involved in birth have been reversed in Brazil, where cesarean sections are now the rule. The authors conclude that health professionals make decisions mainly in terms of financial considerations, convenience, and timing. Their motivations include the desire to deliver quickly in order to attend other patients or perform other activities. The following statements were cited by the authors (Oliveira and Penna, 2018):

Good labor for me is fast, I don't like when it gets dragged out and miserable. I support smooth natural childbirth, that progresses as it should. But we also have to think, because according to what women believe we do cesareans on everyone.

In my heart of hearts, I would do a cesarean on everyone, because after thirty years in this profession, it's exhausting, and vaginal childbirth is stressful; but you have to follow the rules, if it were up to me I would do a cesarean on everyone. I tell you this because here in the region everyone says that we 
kill children in the hospital, there is no praise, it's only criticism. And women who are afraid cause trouble.

Professionals blame pregnant women for the high cesarean rates, as seen in the statements below (Oliveira and Penna, 2018):

The woman is already thinking "I want a cesarean section," I used to try to convince her, but couldn't, so I'd say, "Okay, it's your problem."

Nowadays the patient doesn't want to feel any pain, doesn't want to labor at all. We see that the patient wants to give birth vaginally, but it's painful, they aren't prepared for the birth.

Some patients, there is no use trying to force them to have a vaginal birth. They may even go into labor, but won't cooperate. If you don't have a structure to offer pain relief, a doula, you won't be able to offer these patients a proper birth. So you can't be too strict with the criteria.

Meanwhile, nursing professionals have stated that it is the doctor who decides what birth method will be used, disregarding the opinion of the pregnant woman; they claim that physicians cite clinical justifications that are not always true in order to convince their patients (Oliveira and Penna ,2018).

In this sense, Fernández Moreno (2007) has noted that masculinized clinical-scientific knowledge has been overestimated, to the detriment of non-physician areas such as nursing and psychology. Lorber and Moore (2002) also credit nurses with the maternal role of attending to emotional needs, while doctors take the paternal role of giving orders to the patient. Meanwhile, in a 2008 study Sanchéz (2008) states that doctors appropriate women's ability to speak, which is considered an object of observation and analysis in the health care process. Bedoya-Ruiz, Angudelo-Suárez, and Restrepo-Ochoa (2020) conclude that capitalism and patriarchy intersect to allow a technocratic model of birth health care systems to 
predominate; this model views birth as a production process that dehumanizes via excessive technology.

Along similar lines, according to Yañez (2015) the policies of economic profitability minimize the time of care, ignoring the feelings and the sociocultural context of women and affecting autonomy. And according to Canevari (2017), within the capitalist context health has become a commercial enterprise that compromises ethical values, which explains the increase in unnecessary cesarean sections in the private sector. In this sense, Bedoya-Ruiz, Angudelo-Suárez, and Restrepo-Ochoa (2020) conclude that medical professionals cannot be singled out for blame, since power is exercised through the economic interests of accumulating capital, which are found at the international level.

\section{Conclusions}

As we have seen, the public policies to promote vaginal delivery in Brazil are not effective. Although there are numerous initiatives in this direction, cesarean rates remain high, especially in the private health care network.

One public policy that targets pregnant women who use private services is the term of consent, which explains the risks of the procedure. This is, however, a technical document, and there is no guarantee that the language will be accessible to the patient.

Meanwhile, the structure for providing care to women during vaginal delivery is guaranteed, regardless of establishment and form of payment. But no public policy addresses the relativity of pain during vaginal delivery or the effectiveness of non-pharmacological pain relief methods. Furthermore, pregnant women seem unaware that cesarean section is a surgery that involves pain after the procedure. 
Also in terms of pain, the studies cited here indicate that pain perception could be linked to obstetric violence during vaginal delivery, showing the impatience of professionals with laboring women. This mode of delivery could lead untrustworthy individuals to use violent methods such as the Kristeller maneuver and episiotomy on these women without consent.

In the private system, women choose what kind of birth they want, but the data shows that the physician still wields significant influence. The sources we have reviewed here indicate that women's preferences shift for some reason during prenatal care from vaginal delivery to cesarean section. Many women tend to believe that the doctor makes the choice, even if they sign the consent form.

In this sense, physician preference is visible: motives include comfort, convenient scheduling, and economic advantage, since cesarean births take less time than vaginal delivery and permit more profitable activities during the same period. Statements from doctors evidence a lack of patience with the pregnant mother's mental state. Physicians claim to like "fast" labor and describe women as uncooperative and unprepared. In this sense, the fragmentation of medicine has led to disregard for women's psychological health. Unfortunately, women are considered incapable of giving birth, and have been removed from an active role in this process.

One of the doctors interviewed pointed out that a doula is needed to provide an adequate birth; in other words, an investment in psychological support for the pregnant woman could encourage vaginal delivery. It is notable that areas such as nursing and psychology, which are considered maternal functions and consequently undervalued, are precisely what pregnant women lack.

In the SUS, cesarean birth rates remain low since they must be medically justified, regardless of the mother's preferences. Furthermore, the lack of a bond between the patient and physician prevents the professional from fabricating reasons for a cesarean 
section that would benefit them economically, since the same doctor is unlikely to accompany the patient over time.

For this reason, in line with the UN's Guiding Principles on Business and Human Rights, private hospitals must work harder to encourage doctors and women to choose the healthiest form of childbirth. In establishing that business activities must not damage human rights and should consider potential negative impacts to human rights associated with these activities, the Principles indicate that private enterprise has an important role to play in finding solutions, which is not seen in Brazil. The responsibility of hospitals, in not taking measures to inform women about the benefits of vaginal delivery and the risks of elective cesarean sections and not taking action against doctors who encourage women to make choices that are not in the best interest of their health, should be investigated.

Finally, the Brazilian government, as the guarantor of human rights and with its powers of oversight, should investigate obstacles to achieving SDG 17 and health in order to better direct public policies that encourage vaginal delivery, considering the cultural and financial aspects discussed herein.

\section{References}

Agência Nacional de Saúde Suplementar. 2015a. "Estímulo ao Parto Normal: Organização da atenção ao pré-natal, parto e nascimento."

http://www.ans.gov.br/images/stories/prestadores/partonorm al/apresentacao-parto-rn368-julho-2015.pdf.

Agência Nacional de Saúde Suplementar. 2015b. "Resolução normativa $\mathrm{n}^{\circ} 368$, de 6 de janeiro de 2015." https://www.ans.gov.br/component/legislacao/?view=legislaca o\&task=TextoLei\&format=raw\&id=Mjg5Mg==.

Agência Nacional de Saúde Suplementar. 2017. "MODELOS DE REMUNERAÇÃO NA SAÚDE SUPLEMENTAR." http://www.ans.gov.br/images/stories/Particitacao_da_socieda 
de/2016_gt_remuneracao/7reuniao_2017_remuneracao_aprese ntacao_karla_coelho2.pdf.

Agência Nacional de Saúde Suplementar. n.d.a "Taxas de partos cesáreos por operadora de plano de saúde.” Accessed January 07, $2020 . \quad$ http://www.ans.gov.br/planos-de-saude-eoperadoras/informacoes-e-avaliacoes-de-operadoras/taxas-departos-cesareos-por-operadora-de-plano-de-saude.

Agência Nacional de Saúde Suplementar. n.d.b "Quem somos." Accessed December 19, 2019. http://www.ans.gov.br/aans/quem-somos.

Agência Nacional de Saúde Suplementar. n.d.c "Programas de Qualificação do setor de Saúde Suplementar.” Accessed January 12 , 2020. http://www.ans.gov.br/images/stories/web_programas_qualifi caca_setor.pdf.

Agência Nacional de Saúde Suplementar. n.d.d "Estímulo ao Parto Normal: Organização da Atenção ao Pré-natal, Parto e Nascimento." Accessed January 7, 2020. http://www.ans.gov.br/images/stories/noticias/Parto_Adequad o_final.pdf.

Barros, Fernando C., José L. D. Rossello, Alicia Matijasevich, Samuel C. Dumith, Aluisio J. D. Barros, Iná S. Dos Santos, Denise Mota, and Cesar G. Victora. 2012. "Gestational age at birth and morbidity, mortality, and growth in the first 4 years of life: findings from three birth cohorts in Southern Brazil". BMC Pediatrics 12, no. 169 (October) https://doi.org/10.1186/14712431-12-169.

Bedoya-Ruiz, Libia A., Andrés A. Agudelo-Suárez, Diego A. RestrepoOchoa. 2020. "Mujeres en embarazo, parto, y posparto: una mirada desde el pensamiento feminista". Rev Peru Med Exp Salud Publica 37, no. 1 (March): 142-47. https://doi.org/10.17843/rpmesp.2020.371.4981.

Brasil. 1988. "Constituicão da República Federativa do Brasil de 1988.” http://www.planalto.gov.br/ccivil_03/constituicao/constituicao .htm.

Brasil. 1990. "Lei $\mathrm{n}^{\circ}$ 8.080, de 19 de setembro de 1990." http://www.planalto.gov.br/ccivil_03/leis/l8080.htm. 
Brasil. 2000. "Portaria $\mathrm{n}^{\circ}$ 572, de $1^{\circ}$ de junho de 2000." http://bvsms.saude.gov.br/bvs/saudelegis/gm/2000/prt0572_0 1_06_2000_rep.html.

Brasil. 2008. "Resolução $\mathrm{n}^{\circ}$ 36, de junho de 2008." http://bvsms.saude.gov.br/bvs/saudelegis/anvisa/2008/res003 6_03_06_2008_rep.html.

Brasil. 2015. "Portaria $\mathrm{n}^{\circ} 11$, de 7 de janeiro de 2015." https://bvsms.saude.gov.br/bvs/saudelegis/gm/2015/prt0011_ 07_01_2015.html.

Brasil. n.d. "Rede Cegonha." Accessed January 10, 2020. https://www.saude.gov.br/saude-para-voce/saude-damulher/rede-cegonha.

Canevari, María Cecilia. 2017. “Las prácticas médicas y la subalternización de las mujeres: Derechos, autonomía y violência”. PhD diss., Universidad de Buenos Aires.

Conselho Federal de Medicina. 2009. "Resolução CFM N 1931/2009" http://www.portalmedico.org.br/resolucoes/cfm/2009/1931_20 09.htm.

Comissão Interamericana de Direitos Humanos. 1969. "Convenção Americana de Direitos Humanos" https://www.cidh.oas.org/basicos/portugues/c.convencao_am ericana.htm.

Comissão Nacional de Incorporação de Tecnologias no SUS. 2016a. "Diretrizes de Atenção à Gestante: a operação cesariana." http://conitec.gov.br/images/Relatorios/2016/Relatorio_Diretri zes-Cesariana_final.pdf.

Comissão Nacional de Incorporação de Tecnologias no SUS. 2016b. "Diretriz Nacional de Assistência ao Parto Normal." http://conitec.gov.br/images/Consultas/2016/Relatorio_Diretri z-PartoNormal_CP.pdf.

Da Silva, Jeniffer E. 2021. “Quanto custa um parto com ou sem plano de saúde?" https://www.planodesaude.net/quanto-custa-partocom-ou-sem-plano-de-saude. 
De Souza, Antônio A., Cynthia O. Lara, Lívia C. M. Lima, Caroline S. S. N. Paviône. 2013. "Análise de Custos em Hospitais: Comparação dos Custos dos Partos Normal e Cesáreo e os Valores Repassados por um Plano de Saúde". Revista de Administração $e$ Contabilidade 5, no. 1 : 50-61. http://www.reacfat.web7003.uni5.net/index.php/reac/article/v iewFile/57/59.

Departamento de Análise de Saúde e Vigilância de Doenças Não Transmissíveis. n.d. "Painel de Monitoramento de Nascidos Vivos segundo Classificação de Risco Epidemiológico (Grupos de Robson)." Accessed January 10, 2020. http://svs.aids.gov.br/dantps/centrais-de-conteudos/paineisde-monitoramento/natalidade/grupos-de-robson/.

Entringer, Aline P., Marcia F. T. Pinto, Maria A. S. M. Gomes. 2019. "Análise de custos da atenção hospitalar ao parto vaginal e à cesariana eletiva para gestantes de risco habitual no Sistema Único de Saúde”. Ciênc. saúde coletiva 24, no. 4 (May): 1527-36. https://doi.org/10.1590/1413-81232018244.06962017.

Entringer, Aline P., Márcia Pinto, Marcos A. B. Dias, and Maria A. S. M. Gomes. 2018. "Análise de custo-efetividade do parto vaginal espontâneo e da cesariana eletiva para gestantes de risco habitual no Sistema Único de Saúde." Cadernos de Saúde Pública 34, no. 5 (May). http://dx.doi.org/10.1590/0102$311 \times 00022517$.

Lorber, Judith, Moore, Lisa J. 2002. Gender and the social construction of illness. Second Edition. Lanham: Altamira Press. p. 37-51.

Ministério da Saúde. 2010. "Parto e nascimento domiciliar assistidos por parteiras tradicionais." http://bvsms.saude.gov.br/bvs/publicacoes/parto_nascimento _domiciliar_parteiras.pdf.

Ministério da Saúde. 2013. "Atenção ao Pré-Natal de Baixo Risco" http://bvsms.saude.gov.br/bvs/publicacoes/atencao_pre_natal _baixo_risco.pdf.

Ministério da Saúde. 2016. "Caderneta da Gestante." https://portalarquivos2.saude.gov.br/images/pdf/2016/marco/ 01/Caderneta-Gest-Internet.pdf. 
Moreno, Sara Y. F. 2007. "La violencia de género en las prácticas institucionales de salud afectaciones del derecho a la salud y a las condiciones de trabajo en salud". Rev Gerenc Polit Salud6, no. 12 (June): $52-76$. https://revistas.javeriana.edu.co/index.php/gerepolsal/article/ view/2699.

Nações Unidas Brasil. 2015a. "Transformando Nosso Mundo: A Agenda 2030 para o Desenvolvimento Sustentável." https://nacoesunidas.org/pos2015/agenda2030/.

Nações Unidas Brasil. 2015b. “Objetivo 3. Assegurar uma vida saudável e promover o bem-estar para todas e todos, em todas as idades." https://nacoesunidas.org/pos2015/ods3/.

FIOCRUZ. 2019. "Nascer no Brasil: Inquérito Nacional sobre Parto e Nascimento." https://nascernobrasil.ensp.fiocruz.br/wpcontent/uploads/2019/12/sumario_executivo_nascer_no_brasil .pdf

OECD. 2005. "Health at a Glance: OECD Indicators." http://www.oecd.org/els/health-systems/35618945.pdf.

Oliveira, Virgínia J., Claudia M. M. Penna. 2018. "Cada parto é uma história: processo de escolha da via de parto". Revista Brasileira de Enfermagem71, no. 3: 1304-12. https:// doi.org/10.1590/00347167-2016-0497

Paixão, Erivelto M., Antônio A. De Souza, Lívia C. M. Lima. 2010. "Custo do parto normal e cesáreo: replicação do custeio ABC," XVII Congresso Brasileiro de Custos. https://anaiscbc.emnuvens.com.br/anais/article/view/686/686

Parto do Princípio. 2012. "Dossiê da Violência Obstétrica: 'Parirás com dor'”.

https://www.senado.gov.br/comissoes/documentos/SSCEPI/D OC\%20VCM\%20367.pdf

Patah, Luciano E. M., Malik, Ana M. Malik. 2011. "Modelos de assistência ao parto e taxa de cesárea em diferentes países". Rev. Saúde Pública 45, no. 1 (February): 185-94. https://doi.org/10.1590/S0034-89102011000100021. 
Sánchez, Dolores. "El discurso médico, piedra angular de la construcción de las relaciones de género en la época contemporânea". Asclepio 60, no. 1 (June): 63-82. https://doi.org/10.3989/asclepio.2008.v60.i1.244.

Soalheiro, Luisa Cordélia. 2012. "Fatores associados à preferência por cesariana em uma amostra representativa de primíparas na Região Sul do Brasil.” Masters diss., Fundação Oswaldo Cruz.

Sobhy, Soha, Shakila Thangaratinam, Javier Zamora, Khalid Khan, Ana P. Betran, Sirisha R. Gundabattula, Evita Fernandez, Inderjeet Kaur, Vinoth Kumar, Gayathri Karthikeyan, Nilaani Murugesu, David Arroyo-Manzano. 2019. "Maternal and Perinatal Mortality and Complications Associated with Caesarean Section in Low-Income and Middle-Income Countries: a Systematic Review and Meta-Analysis." The Lancet 393, no. 10184 (March): 1973-82. 11, 2019. https://doi.org/10.1016/S0140-6736(18)32386-9

UN GLOBAL COMPACT. n.d. "Pacto Global.” Accessed December 17, 2019. https:/ / www.pactoglobal.org.br/a-iniciativa.

UNICEF. 2017. "Quem espera, espera." https://www.unicef.org/brazil/media/3751/file/Quem_espera_ espera.pdf.

Velho, Manuela B., Evanguelia K. A. Santos, Vânia S. Collaço. 2014. "Parto normal e cesárea: representações sociais de mulheres que os vivenciaram". Revista Brasileira de Enfermagem 67, no. 2 (March/April): 282-89. https://doi.org/10.5935/00347167.20140038.

World Health Organization. 2018. "WHO recommendations: Intrapartum care for a positive childbirth experience." https://apps.who.int/iris/bitstream/handle/10665/260178/9789 241550215-eng.pdf?sequence $=1$.

World Health Organization. n.d.a "About WHO: Better health for everyone, everywhere." Accessed January 10, 2020. https://www.who.int/about.

World Health Organization. n.d.b "Maternal health: WHO's work." Accessed January 10, 2020. https://www.who.int/healthtopics/maternal-health\#tab=tab_1. 
Yañez, Sabrina Soledad. 2015. "De cómo las instituciones de salud pública regulan las experiencias de embarazo, parto $\mathrm{y}$ puerperio... y de lo que resta (Mendoza, 2001-2013)". PhD diss., Universidad de Buenos Aires. 